(Q)
SPEDM

Artigo de Revisão

\title{
Height Impact of Somatotropin in Cancer Survivors
}

\author{
Catarina Pereira ${ }^{\text {a, }}$, Joana Serra Caetano a, Alice Carvalho ${ }^{\text {b }}$, Manuel Brito ${ }^{\text {b }}$, Rita Cardoso a, \\ Isabel Dinis ${ }^{a}$, Alice Mirante ${ }^{a}$
}

${ }^{a}$ Pediatric Endocrinology, Diabetes and Growth Unit, Pediatric Hospital, Coimbra Hospital and University Centre, Coimbra, Portugal

${ }^{b}$ Pediatric Oncology Service, Pediatric Hospital, Coimbra Hospital and University Centre, Coimbra, Portugal

\author{
INFORMAÇÃO SOBRE O ARTIGO \\ Historial do artigo: \\ Received/ Recebido: 2019-08-16 \\ Accepted/Aceite: 2020-11-15 \\ Final: 2021-01-19 \\ (C) Autor (es) (ou seu (s) empregador (es)) e \\ Revista SPEDM 2020. Reutilização permitida \\ de acordo com CC BY-NC. Nenhuma \\ reutilização comercial. \\ (C) Author(s) (or their employer(s)) and SPEDM \\ Journal 2020. Re-use permitted under CC BY-NC. \\ No commercial re-use.
}

\section{Keywords:}

Body Height/drug effects;

Child Development/drug effects;

Growth Hormone/therapeutic use;

Neoplasms/complications;

Survivors.

\begin{abstract}
A B S T R A C T
Introduction: Somatotropin deficiency is the most common endocrinopathy in childhood cancer survivors. However, studies of final height in these patients treated with somatotropin are limited. Thus, this study was performed to examine their growth outcomes.

Methods: A retrospective analysis was performed, including all childhood cancer survivors treated with somatotropin in a pediatric endocrinology department, between 1988 and 2016. Statistical analysis was performed.

Results: Twenty-seven cancer survivors with a median of 5.5 years of age at diagnosis were included; 16 (59.3\%) had central nervous system cancer; 19 (70.4\%) were submitted to radiotherapy. Concomitant endocrinopathies existed in 14 (51.9\%). Somatotropin treatment was started at a median age of 11.13 years with a median duration of 4.1 years. The initial height was -2.30 standard deviation score (SDS) and increased to -1.81 SDS by 1 year, -1.68 SDS by 2 years, and -1.56 SDS by 3 years under somatotropin treatment. There were significant differences in height between the beginning and by 1 year $(p<0.001)$, by 1 and 2 years $(p=0.006)$ and between initial and the end of treatment $(p=0.022)$. However, the adult height was significantly lower than the midparental height $(p=0.011)$, with no differences associated with gender, group of cancer, radiotherapy, concomitant endocrinopathies, age or pubertal stage at beginning.

Conclusion: We concluded that the improvement of linear growth was significant, mainly in the first year of treatment, but these patients did not achieve their genetic potential for height. Physicians must be aware and search for somatotropin deficiency in cancer survivors and treatment should be started as soon as possible.
\end{abstract}

\section{Palavras-chave:}

Desenvolvimento da Criança/efeitos dos fármacos;

Estatura/efeitos dos fármacos;

Hormona do Crescimento/uso terapêutico;

Neoplasias/complicações;

Sobreviventes.

\section{O Impacto na Estatura da Somatotropina em Sobreviventes Oncológicos}

\section{R E S U M O}

Introdução: A deficiência de somatotropina é a endocrinopatia mais comum em sobreviventes de cancro em idade pediátrica. No entanto, estudos sobre a estatura final destes doentes tratados com somatotropina são escassos, pelo que o objetivo deste estudo foi avaliar o crescimento destes doentes. Métodos: Foi realizada uma análise retrospetiva, incluindo todos os sobreviventes de cancro em idade pediátrica tratados com somatotropina numa unidade de endocrinologia pediátrica, entre 1988 e 2016. Foi realizada a análise estatística dos dados.

\footnotetext{
*Autor Correspondente / Corresponding Author.

E-Mail: catarinaopereira@gmail.com (Catarina de Oliveira Pereira)

Rua Quinta da Várzea, lote 6, $2^{\circ} \mathrm{B}, 3040-380$ Coimbra, Portugal
} 
Resultados: Foram incluídos vinte e sete sobreviventes oncológicos, com uma mediana de 5,5 anos de idade aquando o diagnóstico da patologia tumoral; 16 (59,3\%) apresentavam neoplasia do sistema nervoso central; $19(70,4 \%)$ tinham sido submetidos a radioterapia. Apresentavam endocrinopatias concomitantes $14(51,9 \%)$. O tratamento com somatotropina foi iniciado com uma idade mediana de 11,13 anos, sendo a duração mediana do tratamento de 4,1 anos. A estatura inicial foi de -2,30 desvio padrão (DP), tendo aumentado para -1,81 DP em 1 ano, -1,68 DP em 2 anos, e -1,56 DP em 3 anos sob tratamento com somatotropina. Houve diferenças estatisticamente significativas na estatura entre o início e o final do primeiro ano $(p<0,001)$, entre o final do primeiro e segundo anos $(p=0,006)$ e entre o início e o final do tratamento $(p=0,022)$. No entanto, a estatura em idade adulta foi significativamente menor que a estatura alvo familiar $(p=0,011)$, sem diferenças no género, grupo de neoplasia, realização de radioterapia, endocrinopatias concomitantes, idade ou estádio pubertário no início do tratamento.

Conclusão: Concluímos que a evolução do crescimento foi significativa, principalmente no primeiro ano de tratamento, ainda assim estes doentes não atingiram o seu potencial genético para a estatura. Os médicos devem estar alerta de modo a procurar a deficiência de somatotropina em sobreviventes oncológicos e a iniciar o tratamento o mais precocemente possível.

\section{Introduction}

Endocrine abnormalities are a common late effect of cancer disease, affecting up to $40 \%$ to $60 \%$ of childhood cancer survivors. ${ }^{1}$ The first and most common endocrinopathy is the deficiency of somatotropin. ${ }^{2}$ It can be due to the cancer location, surgery extent, treatment effects on the hypothalamic-pituitary axis and/or cranial irradiation, a leading cause of hypothalamic and pituitary injury. ${ }^{1-4}$ Somatotropin is important not only for linear growth but also for metabolic functions, an adequate body composition and for enhancement of pubertal growth. ${ }^{1,5,6}$ Besides somatotropin deficiency, growth is also affected by spinal irradiation, other endocrinopathies (such as untreated precocious puberty and hypothyroidism), excessive doses of exogenous glucocorticoids and poor nutrition. ${ }^{1,2}$ Particular attention should be taken to puberty timings since a precocious puberty can disguise a low growth velocity and somatotropin deficiency might be missed.

This pathology usually manifests with slow growth velocity with decline in height standard deviation score (SDS), delayed skeletal maturation, low levels of insulin-like growth factor 1 (IGF-1) and inadequate somatotropin secretory response to pharmacologic secretagogues. ${ }^{2}$

The diagnosis of somatotropin deficiency has been the subject of controversy requiring clinical and auxological criteria and evaluation of IGF-1 levels and of bone age. ${ }^{5}$ According to the National Commission on Growth Hormone Normalization of Portugal, the auxological criteria that demand investigation in these patients are: height under -2 SDS or variation in height-for-age z-score under percentile 3 for one year or under percentile 10 for two years.

During the diagnostic investigation and follow-up of childhood cancer survivors, physicians should be alert to the frequent association between somatotropin and other pituitary hormone deficiencies. ${ }^{5}$

Somatotropin replacement therapy is effective in promoting a better linear growth ${ }^{2}$ and it seems to be safe, with no evidence of an increased risk of cancer recurrence..$^{1,5,8}$ The association between somatotropin treatment and the risk of second cancers is insufficient to preclude its use for licensed indications. ${ }^{8}$ There is few information about the appropriate interval between completion of cancer therapy and initiation of somatotropin treatment, ${ }^{8}$ but, according to our national consensus, the treatment should only be done after at least one year in remission.?

The primary goal of this treatment is normalization of height in order to achieve the expected adult height. ${ }^{5}$ However, studies of final height in childhood cancer survivors treated with somato- tropin are limited; and there are very few studies of final height in cancer survivors in Portugal.

The aim of this study was to evaluate growth outcomes in these patients by assessing and comparing adult height with midparental height. We also wanted to evaluate stature gain along treatment and the possible differences according to gender, cancer type, history of radiotherapy, concomitant endocrinopathies, stage of puberty and age at the beginning of treatment.

\section{Material and Methods}

A retrospective analysis was done, through the evaluation of the clinical records, on paper and using a medical software $\left(\right.$ SClínico $\left.^{\circledR}\right)$. All childhood cancer survivors treated with somatotropin in our pediatric endocrinology department, between 1988 and 2016, were included. We analysed demographic variables, data regarding the oncological disease (age at diagnosis, cancer type and type of treatment), criteria to establish somatotropin deficiency (using references values, ${ }^{9,10}$ ), concomitant endocrinopathies, the age and pubertal stage at somatotropin treatment start, the somatotropin dosages, height along treatment, body mass indexes (BMI), IGF-1 levels and bone age over the first three years of treatment, midparental height and adult height (height at least with 18 years of age, with an annual increment less than $0.5 \mathrm{~cm}$ ). Statistical analysis was performed using Excel ${ }^{\circledR}$ software version of 2013 and SPSS $^{\circledR}$ software version 24 . The characterization of the population was performed by calculating measures of central tendency and dispersion for quantitative variables and by determining absolute and relative frequencies for qualitative variables. To analyse the evolution of variables over time, Wilcoxon's test was used. To compare variables between two independent groups we used the U-Mann-Whitney test. The Spearman correlation was used to measure the strength of association between two continuous variables. A level of statistical significance of $5 \%$ was considered.

\section{Results}

During the study period, 27 cancer survivors were included, $63.0 \%(n=17)$ of male gender. The median age at cancer diagnosis was 5.54 years [interquartile range (IQR) 2.67; 7.21], with a minimum of three months and a maximum of 10 years. Of the sample, $59.3 \%(n=16)$ had central nervous system cancers - Table 1, being the medulloblastoma the most frequent one; $59.3 \%(n=16)$ undertook surgery, $70.4 \%(n=19)$ radiotherapy and $66.7 \%(n=18)$ chemotherapy. The median dose of prior radiation was 47.3 Gy 
Table 1. Criteria for somatotropin deficiency diagnosis of the sample.

\begin{tabular}{lcc}
\hline & $\mathbf{n}$ & $\mathbf{\%}$ \\
\hline $\begin{array}{l}\text { Variation in height-for-age z-score }<\text { percentile } 10 \\
\text { for 2 years or }<\text { percentile 3 for 1 year }\end{array}$ & 19 & 70.4 \\
\hline Height $<-2$ SDS & 12 & 44.4 \\
\hline IGF-1 <-2 SDS & 11 & 40.7 \\
\hline SDS - standard deviation score
\end{tabular}

(IQR 24; 76.6). Neuroaxis radiation was performed in 13, with median radiation dose of 24 Gy (IQR 18; 34.5). Cranial radiation was performed in 12, with median dose of 49.7 Gy (IQR 45; 54). Seven of these were also irradiated in neuroaxis.

The most frequent criteria to investigate somatotropin deficiency was low variation in height-for-age $\mathrm{z}$-score, presented in $70.4 \%(n=19)$. Table 2 shows the criteria that led to the investigation of somatotropin deficiency.

The provocative test was undertaken by 15 patients, all with inadequate somatotropin secretory response with the exception of one patient, that matched auxological criteria by itself: low IGF1 (-2.25 SDS), low SDS of stature (-2.68), and low variation in height-for-age $\mathrm{z}$-score for one year.

There were at least one concomitant endocrinopathy in $51.9 \%$ $(n=14)$ of patients: central hypothyroidism in $44.4 \%(n=12)$, diabetes insipidus in $22.2 \%(\mathrm{n}=6)$, adrenocorticotropic hormone deficiency in $18.5 \%(n=5)$, hypogonadism in $7.4 \%(n=2)$ and panhypopituitarism (inadequate or absent production of all pituitary hormones) in $3.7 \%(n=1)$.

Somatotropin treatment began at a median age of 11.13 years (IQR $8.88 ; 12.24)$, with a minimum of four years and eight months and a maximum of 14 years and seven months. The Table 3 shows the evolution of dosage, height, body mass index, IGF-1 and the difference between chronological age and bone age over the first three years of treatment.

The initial height was -2.30 SDS and increased to -1.81 SDS by one year, -1.68 SDS by two years, and -1.56 SDS by three years with somatotropin treatment, with significant differences between the initial height and by one year $(p<0.001)$ and by one and two years $(p=0.006)$. There was no significant difference between the end of the second and the end of the third years $(p=0.095)$ - Fig. 1 .

The BMI decreased significantly in the first year of treatment ( $p=0.002$ ), with no more significant differences between the BMI along time $\left(1^{\text {st }} v s 2^{\text {nd }}\right.$ years: $p=0.775 ; 2^{\text {nd }} v s 3^{\text {rd }}$ years: $\left.p=0.587\right)$. The initial IGF-1 concentration was $-1,93$ SDS and increased signifi-

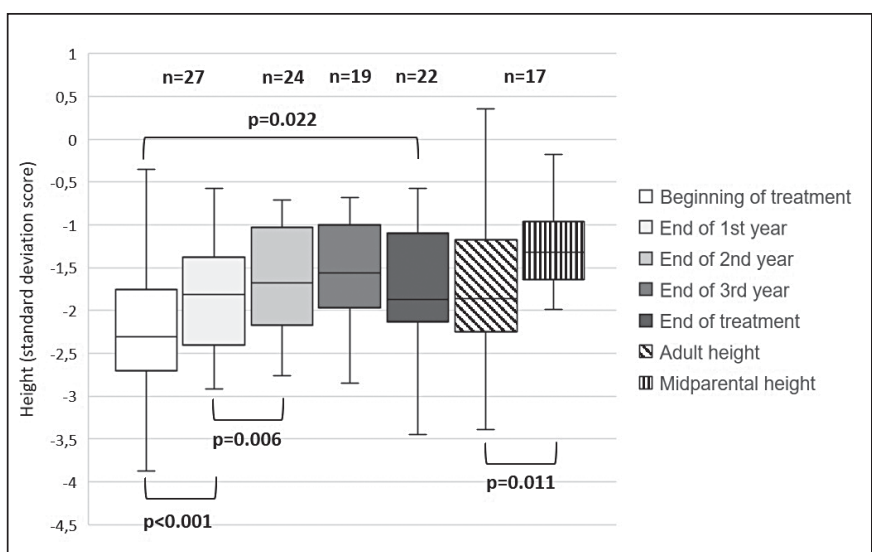

Figura 1. Evolution of height over the first three years of treatment, height at the end of treatment, adult height and midparental height of the sample.

cantly to 0.93 SDS by one year $(p<0.001)$. It continued to increase, in a significant way, throughout the second year $(p=0.008)$ and then it decreased $(p=0.049)$. The differences between chronological and bone age decreased throughout the treatment with a significant difference between the beginning and the third year of treatment $(p=0.047)$.

The median treatment duration was of 4.09 years (IQR 2.52; 5.50 ), with minimum of one year and four months and maximum of 11 years. At the end of treatment, height was statistically higher [-1.87 SDS (IQR -2.13; -1.10)] and BMI was lower [0.45 SDS (IQR - $0.66 ; 1.33)]$ but with no statistical difference comparing to the beginning ( $p=0.022$ and 0.068 , respectively).

We obtained the adult height of $17 / 27$ patients [-1.86 (IQR -2.24; -1.17)]. In this group, there were statistical differences in height in the first two years of treatment (initial versus first year: $p=0.001$; first versus second years: $p=0.012$ ). Despite that, there were no differences between the initial and the end of treatment $(p=0.056)$ and the adult height was significantly lower than the midparental height [-1.32 (IQR -1.63; -0.96)], with $p=0.011$ - Fig. 1 .

The difference between adult height and midparental height was not associated with gender $(p=0.897)$, group of cancer ( $p=0.328)$, to have done radiotherapy $(p=0.959)$, concomitant endocrinopathies $(p=0.139)$ or age or pubertal stage at the beginning of treatment ( $p=0.823$ and 0.481 , respectively).

The reasons for suspending treatment were: growth velocity less than two centimetres per year $(n=9)$, own initiative $(n=2)$, relapse of cancer disease $(n=2$, one with anaplastic ependymoma and another with neuroblastoma), loss of follow-up ( $n=1$, at the sixth year of treatment) and no information in the medical record $(n=9)$. At the time of this study, four patients were still under treatment.

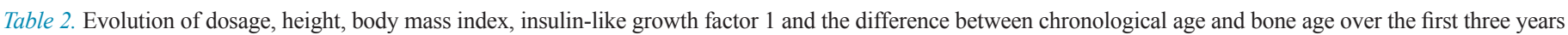
of treatment. Data in median (Q1; Q3).

\begin{tabular}{|c|c|c|c|c|}
\hline & The beginning $(n=27)$ & End of $1^{\text {st }}$ year $(n=27)$ & End of $2^{\text {nd }}$ year $(n=24)$ & End of $3^{\text {rd }}$ year $(n=19)$ \\
\hline Dosage $(\mu \mathrm{g} / \mathrm{kg} /$ day $)$ & $33(28 ; 34)$ & $32(25 ; 34)$ & $31(23 ; 34)$ & $30(30 ; 40)$ \\
\hline Height (SDS) & $-2.30(-2.70 ;-1.75)$ & $-1.81(-2.40 ;-1.38)$ & $-1.68(-2.17 ;-1.03)$ & $-1.56(-1.97 ;-1.00)$ \\
\hline BMI (SDS) & $0.87(-0.69 ; 1.51)$ & $0.41(-0.64 ; 1.06)$ & $0.52(-0.93 ; 1.25)$ & $-0.16(-0.97 ; 0.87)$ \\
\hline IGF-1 (SDS) & $-1.93(-2.47 ;-0.65)$ & $0.93(-0.78 ; 2.02)$ & $1.19(0.45 ; 2.75)$ & $0.86(-0.62 ; 1.78)$ \\
\hline CA-BA (years) & $1.41(-0.32 ; 1.80)$ & $0.22(-0.13 ; 1.36)$ & $0.50(-0.44 ; 1.15)$ & $0.43(0.00 ; 1.14)$ \\
\hline
\end{tabular}

BA - bone age, BMI - body mass index, CA - chronological age, SDS - standard deviation score 


\section{Discussion and Conclusion}

As described in literature, the most common oncological disease was central nervous system cancer, mainly medulloblastoma. ${ }^{2,12}$ The management of brain cancers typically involves local surgery, chemotherapy and radiotherapy, all contributing to the injury in the hypothalamic-pituitary region. ${ }^{2}$ Radiotherapy, a known risk factor for somatotropin deficiency in childhood cancer survivors, ${ }^{3}$ was performed on most of the patients. It is important to note that older therapeutic protocols included higher doses of radiotherapy and a greater extension of irradiated area.

In our sample, the improvement of linear growth was significant, especially in the first year of treatment with somatotropin, similar to that described by Chae et al, which included survivors of medulloblastoma. ${ }^{12}$ Although our patients improved height with somatotropin treatment, they did not achieve their genetic potential for height. These results are similar to those found in literature, ${ }^{2}$ including a belgian study with 57 childhood brain cancer survivors. ${ }^{13}$ Besides the loss of opportunity during the disease and others comorbidities, one of the reasons that may explain why these patients do not reach midparental height is the direct effect of radiation on the spine, especially those who received radiation at a younger age or had a lower height at the start of somatotropin therapy. ${ }^{14}$

The diagnosis of somatotropin deficiency in cancer survivors is challenging, requiring the evaluation of several clinical elements rather than the use of just one test. ${ }^{2}$ In our group, the provocative test was performed only in 15 patients but, according to the National Commission on Growth Hormone Normalization, in cases of children with auxological criteria submitted to central nervous system or spinal irradiation, it is not necessary to perform somatotropin provocative tests. ${ }^{7}$ This test was normal in one patient with auxological criteria compatible with somatotropin deficiency, IGF-1 concentration more than two SDS below the mean and with height improvement with treatment. Probably this patient had a condition called growth hormone neurosecretory dysfunction, a specific form of somatotropin deficiency following radiation damage, that is characterized by diminished somatotropin secretion yet preserved peak somatotropin response to provocative testing. ${ }^{2,5}$

Regarding concomitant endocrinopathies, hypothyroidism was the most frequent one, as expected. ${ }^{3}$ Cancer survivors require close monitoring of thyroid hormones levels, which are also implicated in the linear growth process. ${ }^{1}$ We found five cases of adrenocorticotrophic hormone deficiency. Adrenal insufficiency has been associated, in a nonconsensual way, with somatotropin treatment because of the physiological effects of somatotropin on glucocorticoid metabolism, reducing the conversion of inactive cortisone to active cortisol, making manifested an underlying adrenal insufficiency. ${ }^{15}$ The endocrine screening is important in these patients and should be started soon after cancer treatment. Manifestations of an endocrine deficiency may be difficult to recognize in the early years of follow-up, when rehabilitation is the priority. ${ }^{6}$ Many times when short stature is recognized it is too late to improve. ${ }^{6}$

These children should be carefully followed since diagnosis and somatotropin deficiency should be considered as soon as growth deceleration or normal growth velocity but with concomitant early pubertal signs appear. Pituitary deficiencies are associated with poor health outcome and somatotropin deficiency was related with decreased muscle mass, less exercise tolerance, abdominal obesity, low energy expenditure and muscle weakness in a group of adult survivors of childhood cancers treated with cranial radiotherapy. ${ }^{16}$ The study of Heinks et al. concluded that somatotropin replacement contributed to ameliorate imminent impairments of quality of life after craniopharyngioma, despite the lack of improvement of height in this sample. ${ }^{17}$

In our study, the duration of somatotropin treatment was variable. Two patients stopped treatment because of cancer relapse, however available data in children do not indicate an increased risk of recurrence of primary cancer in survivors. ${ }^{8}$

Finally, the authors evaluated the possible differences in height according to gender, cancer type, history of radiotherapy concomitant endocrinopathies, stage of puberty and age at the beginning of treatment, with no statistical differences between the groups. Probably, these results are due to the small group of patients. Radiotherapy is an important risk factor for somatotropin deficiency. ${ }^{3,18}$ Studies show that the diagnosis of somatotropin deficiency and its treatment should start at the youngest possible age, being important to maximize height with somatotropin treatment before the onset of puberty. ${ }^{5,12}$ There is no consensus in relation to the role of gender. ${ }^{5}$ In the belgian study previously mentioned, no differences were found between females and males, between prepubertal and pubertal patients and between those who had other pituitary hormone deficiency and those with isolate somatotropin deficiency. ${ }^{13}$

Our study was a long-term retrospective study, which included a small and heterogeneous group of patients, with a wide variety of cancer diseases and treatments. In addition, there was not enough data regarding type and evolution of oncological treatments along time (like type of chemotherapy or surgery). Besides that, we believe that treatment with somatotropin was started too late considering the difference between the age at cancer diagnosis and at somatotropin treatment start. Also, it was difficult to confirm if there was a strict compliance of the treatment. Prospective studies with larger samples of patients are needed.

In the present study, we concluded that, despite the significant height improvement, especially in the first year of treatment, the patients did not achieve the midparental height. These results show how difficult it is to overcome the sequelae in height of the cancer disease and its treatments. Thus, the physicians must be aware and search for this endocrinopathy in this group of patients for a lifetime, with regular clinical evaluations every 6 to 12 months. ${ }^{19}$ If there is a decrease in the growth velocity, the diagnosis of somatropin deficit should be evoked and, if indicated, a provocative test should be performed. The physicians must be aware of possible signs of early puberty. Treatment should be started as soon as possible, in order to improve their quality of life. ${ }^{1,4}$

\section{Responsabilidades Éticas}

Conflitos de Interesse: Os autores declaram a inexistência de conflitos de interesse na realização do presente trabalho.

Fontes de Financiamento: Não existiram fontes externas de financiamento para a realização deste artigo.

Confidencialidade dos Dados: Os autores declaram ter seguido os protocolos da sua instituição acerca da publicação dos dados de doentes.

Proteção de Pessoas e Animais: Os autores declaram que os procedimentos seguidos estavam de acordo com os regulamentos estabelecidos pelos responsáveis da Comissão de Investigação Clínica e Ética e de acordo com a Declaração de Helsínquia da Associação Médica Mundial.

Proveniência e Revisão por Pares: Não comissionado; revisão externa por pares. 


\section{Ethical Disclosures}

Conflicts of interest: The authors have no conflicts of interest to declare.

Financing Support: This work has not received any contribution, grant or scholarship

Confidentiality of Data: The authors declare that they have followed the protocols of their work center on the publication of data from patients.

Protection of Human and Animal Subjects: The authors declare that the procedures followed were in accordance with the regulations of the relevant clinical research ethics committee and with those of the Code of Ethics of the World Medical Association (Declaration of Helsinki).

Provenance and Peer Review: Not commissioned; externally peer reviewed.

\section{References / Referências}

1. Sklar C, Friedman DN. Endocrinopathies in cancer survivors and others exposed to cytotoxic therapies during childhood. [Accessed: 13 March 2019] Available at: https://www.uptodate.com/contents/endocrinopathiesin-cancer-survivors-and-others-exposed-to-cytotoxic-therapies-duringchildhood.

2. Mostoufi-Moab S, Grimberg A. Pediatric brain tumor treatment: growth consequences and their management. Pediatr Endocrinol Rev. 2010;8:6-17.

3. Vatner RE, Niemierko A, Misra M. Endocrine deficiency as a function of radiation dose to the hypothalamus and pituitary in pediatric and young adult patients with brain tumors. J Clin Oncol. 2018;36:2854-62. doi: 10.1200/JCO.2018.78.1492.

4. Mostoufi-Moab S, Seidel K, Leisenring WM. Endocrine abnormalities in aging survivors of childhood cancer: a report from the Childhood Cancer Survivor Study. J Clin Oncol. 2016;34:3240-7. doi: 10.1200/ JCO.2016.66.6545.

5. Growth Hormone Research Society. Consensus guidelines for the diagnosis and treatment of growth hormone $(\mathrm{GH})$ deficiency in childhood and adolescence: summary statement of the GH Research Society. J Clin Endocrinol Metab. 2000;85:3990-3. doi: 10.1210/jcem.85.11.6984.

6. Clement SC, Meeteren AY, Kremer LC, van Trotsenburg AS, Caron HN, van Santen HM. High prevalence of early hypothalamic-pituitary damage in childhood brain tumor survivors: need for standardized followup programs. Pediatr Blood Cancer. 2014;61:2285-9. doi: 10.1002/ pbc. 25176 .
7. Comissão Nacional de Normalização da Hormona do Crescimento (CNNHC). Avaliação de crianças e adolescentes com baixa estatura. Lisboa: Ministério da Saúde; 2004.

8. Allen DB, Backeljauw P, Bidlingmaier M, Biller BM, Boguszewski M, Burman P, et al. GH safety workshop position paper: a critical appraisal of recombinant human $\mathrm{GH}$ therapy in children and adults. Eur J Endocrinol. 2016;174:P1-9. doi: 10.1530/EJE-15-0873.

9. Hermanussen M. Auxology: Studying Human Growth and Development. Stuttgart: Schweizerbart Science Publishers; 2013.

10. Brabant G, von zur Mühlen A, Wüster C, Ranke MB, Kratzsch J, Kiess W, et al. Serum insulin-like growth factor I reference values for an automated chemiluminescence immunoassay system: results from a multicenter study. Horm Res. 2003;60:53-60. doi: 10.1159/000071871.

11. Steliarova-Foucher E, Stiller C, Lacour B, Kaatsch P. International Classification of Childhood Cancer, third edition. Cancer. 2005;103:145767. doi: 10.1002/cncr.20910.

12. Chae HW, Park YS, Kim DS, Kwon AR, Kim HS, Kim DH. Final height and insulin-like growth factor-1 in children with medulloblastoma treated with growth hormone. Childs Nerv Syst. 2013;29:1859-63. doi: 10.1007/ s00381-013-2124-6.

13. Beckers D, Thomas M, Jamart J, Francois I, Maes M, Lebrethon MC, et al. Adult final height after $\mathrm{GH}$ therapy for irradiation-induced $\mathrm{GH}$ deficiency in childhood survivors of brain tumors: the Belgian experience. Eur J Endocrinol. 2010;162:483-90. doi: 10.1530/EJE-09-0690.

14. Aslan IR, Cheung CC. Early and late endocrine effects in pediatric central nervous system diseases. J Pediatr Rehabil Med. 2014;7:281-94. doi 10.3233/PRM-140299.

15. Grimberg A, DiVall SA, Polychronakos C, Allen DB, Cohen LE, Quintos JB, et al. Guidelines for Growth Hormone and Insulin-Like Growth Factor-I Treatment in Children and Adolescents: Growth Hormone Deficiency, Idiopathic Short Stature, and Primary Insulin-Like Growth Factor-I Deficiency. Horm Res Paediatr. 2016;86:361-97. doi: $10.1159 / 000452150$.

16. Chemaitilly W, Li Z, Huang S, Ness KK, Clark KL, Green DM, et al. Anterior hypopituitarism in adult survivors of childhood cancers treated with cranial radiotherapy: a report from the St Jude Lifetime Cohort Study. J Clin Oncol. 2015;33:492-500. doi: 10.1200/JCO.2014.56.7933.

17. Heinks K, Boekhoff S, Hoffmann A. Quality of life and growth after childhood craniopharyngioma: results of the multinational trial KRANIOPHARYNGEOM 2007. Endocrine. 2018;59:364-72. doi: 10.1007/s12020-017-1489-9.

18. Sampaio M, Oliveira A, Soro I, Costa C, Castro-Correia C, Fontoura M. Tratamento com hormona de crescimento em sobreviventes pediátricos de doença oncológica. Acta Med Port. 2011;24:393-98.

19. Sklar CA, Antal Z, Chemaitilly W, Cohen LE, Follin C, Meacham LR, et al. Hypothalamic-pituitary and growth disorders in survivors of childhood cancer: an endocrine society clinical practice guideline. J Clin Endocrinol Metab. 2018;103:2761-84. doi: 10.1210/jc.2018-01175. 